\title{
Optimisation of fungal glucoamylase production by Response Surface Methodology and characterisation of the purified enzyme
}

\author{
Tapasi Polley \& Uma Ghosh ${ }^{*}$ \\ Department of Food Technology \& Biochemical Engineering, Jadavpur University, Kolkata700 032, West Bengal, India \\ *Email: ughoshftbe@yahoo.co.in
}

\section{ARTICLE HISTORY}

Received: 25 February 2020

Accepted: 13 June 2020

Published: 28 July 2020

\section{KEYWORDS}

Glucoamylase; Aspergillus niger; Solid-state fermentation; Response surface methodology

\begin{abstract}
A statistical approach was made for the production of glucoamylase by Aspergillus niger using wheat bran and green gram as fermentation medium. Box-Behnken design used to analyse the simultaneous impact of the substrate, hydration, inoculum volume, fermentation time and temperature, using a second-order polynomial. The experimental results were in good agreement with the proposed regression model with $\mathrm{R}^{2}=0.9322(\mathrm{p}<0.05)$. The maximum yield ( $313 \mathrm{U} /$ gds against the predicted value of $306 \mathrm{U} / \mathrm{gds}$ ) was obtained using $12 \mathrm{gm}$ substrate, 55\% moisture, $1 \mathrm{gm}$ sucrose and 0.05 gm tryptone. The purification and characterisation of the enzyme were also studied. Optimum thermal and $\mathrm{pH}$ stability was $60^{\circ} \mathrm{C}$ and 5 respectively.
\end{abstract}

\section{Introduction}

Starch-degrading enzymes such as glucoamylase have applications for dextrose production, confectionery, baking and in pharmaceuticals (1).

Glucoamylase hydrolyses starch producing glucose as sole end-product. Due to the growing demand for these enzymes in several industries, there is enormous interest in developing enzymes with better properties such as raw starch degrading amylase suitable for industrial applications and their cost-effective production techniques (2).

Conventionally, submerge fermentation done for the production of glucoamylase enzyme, though, solidstate fermentation has gained increased interest to produce this enzyme. In solid-state fermentation, the substrate is used as a source of nutrients for the growth of microbial cells. In general, the agroindustrial residue as the best substrates for solid-state fermentation processes (3). Solid-state fermentation (SSF) processes are used for the production of various types of products such as enzymes organic acids, alcohol and antibiotics (4). Enzymes produce from moulds is significant interest in using SSF (5). Optimisation of different parameters is required to attain better enzyme yield. The factors which can affect enzyme production significantly are temperature, $\mathrm{pH}$, agitation, incubation time and agricultural residue (6). To design the fermentation process with a maximum production of an enzyme, optimisation of these physical parameters is much needed. Optimization of process parameters by one variable at a time methods involving changes during all the variables is time consuming and costly when huge numbers of variables are measured (7).

This can be resolved by response surface methodology (RSM) using Box-Behnken design. The statistical design is systematic and fruitful to cover a size able experimental space with limited no of measurements. Therefore, the application of RSM in the production of enzyme and other different processes is acquiring importance (8).

The present study explores the optimisation of fermentation parameters statistically to get a better yield of glucoamylase produced by SSF and the optimisation of glucoamylase production by SSF using RSM and characterisation of the partially purified enzyme.

(c) Polley \& Ghosh (2020). This is an open-access article distributed under the terms of the Creative Commons Attribution License, which permits unrestricted use, distribution and reproduction in any medium, provided the original author and source are credited (https://creativecommons.org/licenses/by/4.0/)

To cite this article: Polley T, Ghosh U. Optimisation of fungal glucoamylase production by Response Surface Methodology and characterisation of the purified enzyme. Plant Science Today. 2020;7(3):456-462. https://doi.org/10.14719/pst.2020.7.3.762 


\section{Materials and Methods}

\section{Microorganism}

The strain Aspergillus niger (NCIM 612), was obtained from the laboratory stock of Food technology and Biochemical Engineering Lab, Jadavpur University, India. The strain was used as an inoculum for further study. This strain was maintained by monthly subcultured on czapekdox agar slant and stored at 4 ${ }^{\circ} \mathrm{C}$.

\section{Fermentation}

The experiments were carried out taking (7, 9.5 and $12 \mathrm{gm}$ ) of wheat bran and green gram mixtusubstrate in $250 \mathrm{ml}$ Erlenmeyer flask and moistened with distilled water (55, 60 and 65\%). The medium was sterilised in an autoclave at $121{ }^{\circ} \mathrm{C}$ for $15 \mathrm{~min}$. The inoculation of the sterile medium was done with a 6 $\mathrm{ml}$ of inoculum and fermentation was continued at $30{ }^{\circ} \mathrm{C}$ temperature for $96 \mathrm{hr}$. The crude enzyme was obtained as an aqueous extract after centrifugation (C-24, REMI, India) at $20000 \mathrm{rpm}$ for $20 \mathrm{~min}$.

\section{Assay of glucoamylase}

Standard method with some modification was used for the assay of glucoamylase (9). Acetate buffer with $\mathrm{pH} 4.8$ was used to prepare $5 \%$ soluble starch solution. The reaction mixture contains (each test tube) $1 \mathrm{ml}$ enzyme, $1 \mathrm{ml}$ of starch solution and $2 \mathrm{ml}$ DNS and incubated in water bath (Eyela, SB 1000) for 5 min. The transmittance of the mixture was observed at $540 \mathrm{~nm}$ on spectrophotometer (Hitachi, J2800), after cooling the assay mixture to room temperature. One unit (U) of glucoamylase is defined as the amount that liberates one $\mu \mathrm{mol}$ of reducing sugar as glucose $/ \mathrm{ml} / \mathrm{min}$ under the assay condition.

\section{Selection of significant variables by Box-Behnken design}

For the selection of significant variables to produce glucoamylase by Aspergillus niger, substrate amount, initial moisture, time, temperature and inoculum were tested and identified via the Box-Behnken design experiment. A total of four variables were selected and each variable was represented at three levels $(-1,0,+1)$. The variables were as follows: substrate amount (7, 9.5, 12 gm) (A), moisture (55, 60, $65 \%)(\mathrm{B})$, sucrose $(0.8,1.0,1.2 \mathrm{gm})(\mathrm{C})$ and tryptone $(0.04,0.05,0.06)(\mathrm{D})$. The experiments were carried out in Erlenmeyer flask containing wheat bran medium that is inoculated with Aspergillus niger. After this fermentation time, the production of glucoamylase was measured (9).

\section{Statistical Analysis and Modeling}

In the system containing four significant independent variables $A, B, C$ and $D$ the mathematical relationship of the response of these variables can be approximated by a quadratic (second degree) polynomial equation:

$$
\begin{aligned}
Y & =\beta_{0}+\beta_{1} A+\beta_{2} B+\beta_{3} C+\beta_{4} D+\beta_{11} A^{2}+\beta_{22} B^{2}+\beta_{33} C^{2} \\
& +\beta_{44} D^{2}+\beta_{12} A B+\beta_{13} A C+\beta_{14} A D+\beta_{23} B C+\beta_{24} B D+\beta_{34} C D
\end{aligned}
$$

Where $\mathrm{Y}$ is the predicted value, $\beta_{0}$ is the constant, $\mathrm{A}$ is the substrate amount (gm), B is initial moisture (\%), C is sucrose (gm) and D is tryptone (gm). The polynomial equation is generated according to the standard method (10).

\section{Purification of glucoamylase}

The extracted crude enzyme was concentrated five times under vacuum in EYELA Rotary Evaporator $\mathrm{N}$ 1000 Japan, followed by precipitation of enzyme at 4 ${ }^{\circ} \mathrm{C}$ using chilled acetone (11). The sample was centrifuged at $5000 \mathrm{rpm}$ for $15 \mathrm{~min}$ at $4{ }^{\circ} \mathrm{C}$. The collection of protein as precipitated was done after centrifugation. Enzyme activity was measured (11) using the precipitate resuspension in $10 \mathrm{ml} 0.1$ (M) acetate buffer $\left(\mathrm{p}^{\mathrm{H}} 4.8\right)$.

\section{DEAE-Cellulose chromatography}

For purification of the enzyme pre-equilibrated DEAE-Cellulose column was used and $10 \mathrm{ml}$ of the resuspended precipitate was eluted with abovementioned acetate buffer with an increase of $\mathrm{NaCl}$ concentration $(0-0.1 \mathrm{M})$ and at a flow rate of $20 \mathrm{ml} / \mathrm{hr}$. (12). $5 \mathrm{ml}$ fractions were collected and it was used for the determination of protein and enzyme activity. The fractions showing enzyme activity was preserved at $4{ }^{\circ} \mathrm{C}$ after freeze drying for further studies.

\section{Gel electrophoresis}

The pure enzyme was used for molecular mass determination by SDS-PAGE. For gel electrophoresis, $12 \%$ gel was used and the detection of protein bands was done by staining with coomassie blue. The polyacrylamide of $5 \%$ was used as staking gel (13). The molecular mass was compared by the markers run parallel to the samples.

\section{Characterization of enzyme}

Optimum temperature and thermal stability

The determination of optimum temperature was carried out using the enzyme- substrate reaction at various temperatures $(30-80)^{\circ} \mathrm{C}$. The thermal stability was measured by incubating the reaction mixture at temperature ranges $30-70{ }^{\circ} \mathrm{C}(\mathrm{pH}$ 4.8) for $120 \mathrm{~min}$. The enzyme activity was measured.

Optimum $\mathrm{p}^{\mathrm{H}}$ and $\mathrm{p}^{\mathrm{H}}$ stability

The enzyme was incubated with the substrate at $\mathrm{pH}$ ranges (4-8) at $60^{\circ} \mathrm{C}$ to study the optimum $\mathrm{pH}$ and $\mathrm{pH}$ stability. Different buffer such as $0.1 \mathrm{mM}$ acetate buffer $\mathrm{pH}$ 4.0-5.0, phosphate buffer $\mathrm{pH}$ 6.0-7.0 and tris buffer $\mathrm{pH} 8$ was used for optimum $\mathrm{pH}$ and $\mathrm{pH}$ stability. The enzyme activity was measured and it reveals as U/gds.

\section{Kinetic parameters $\left(\mathrm{K}_{\mathrm{m}}\right.$ and $\left.\mathrm{V}_{\max }\right)$}

Different concentration of starch $(1.0-5.0 \mathrm{mg} / \mathrm{ml})$ was used in glucoamylase assay and the activity was plotted in Lineweaver Burk plot against different starch concentration. From the plot $\mathrm{k}_{\mathrm{m}}$ and $\mathrm{v}_{\max }$ was determine. 


\section{Results and Discussion}

\section{Optimisation of variables by Box-Behnken design}

To make the enzyme production cost-effective agricultural residue wheat bran and green gram mixture were studied as the medium for the production of glucoamylase. The variables were significantly important for enzyme production. Optimisation of growth conditions was important for the production of glucoamylase having a higher yield. Table 1 represents the range of variables selected for Box Behnken design. Fermentation condition for glucoamylase production was optimised by RSM. Twenty-nine experiment runs were studied with a different combination of four factors to optimise the fermentation conditions.

The factorial analysis was done considering substrate amount, moisture, sucrose and tryptone marked as A, B, C \& D respectively in this study. The experimental response against independent variables obtained from the regression equation is shown in Table 1. The maximum yield of glucoamylase 313 U/gds was obtained against run no-2 and the minimum, $71 \mathrm{U} / \mathrm{gds}$ against run no-14.

Table 1. Box -Behnken design matrix with experimental glucoamylase production by Aspergillus niger.

\begin{tabular}{|c|c|c|c|c|c|c|}
\hline Run No. & $\begin{array}{l}\text { A. Substrate } \\
\text { amount (gm) }\end{array}$ & B. Moisture (\%) & $\begin{array}{l}\text { C. Sucrose } \\
\text { (gm) }\end{array}$ & $\begin{array}{c}\text { D. Tryptone } \\
\text { (gm) }\end{array}$ & $\begin{array}{l}\text { Actual value } \\
\text { (U/gds) }\end{array}$ & $\begin{array}{c}\text { Predicted } \\
\text { value } \\
\text { (U/gds) }\end{array}$ \\
\hline 1 & 7.0 & 55 & 1.0 & 0.05 & 263 & 281 \\
\hline 2 & 12 & 55 & 1.0 & 0.05 & 313 & 306 \\
\hline 3 & 7.0 & 65 & 1.0 & 0.05 & 182 & 201 \\
\hline 4 & 12 & 65 & 1.0 & 0.05 & 233 & 227 \\
\hline 5 & 9.5 & 60 & 0.8 & 0.04 & 142 & 135 \\
\hline 6 & 9.5 & 60 & 1.2 & 0.04 & 178 & 196 \\
\hline 7 & 9.5 & 60 & 0.8 & 0.06 & 117 & 111 \\
\hline 8 & 9.5 & 60 & 1.2 & 0.06 & 203 & 222 \\
\hline 9 & 7.0 & 60 & 1.0 & 0.04 & 142 & 159 \\
\hline 10 & 12 & 60 & 1.0 & 0.04 & 257 & 250 \\
\hline 11 & 7.0 & 60 & 1.0 & 0.06 & 207 & 225 \\
\hline 12 & 12 & 60 & 1.0 & 0.06 & 192 & 186 \\
\hline 13 & 9.5 & 55 & 0.8 & 0.05 & 284 & 278 \\
\hline 14 & 9.5 & 65 & 0.8 & 0.05 & 71 & 65 \\
\hline 15 & 9.5 & 55 & 1.2 & 0.05 & 213 & 230 \\
\hline 16 & 9.5 & 65 & 1.2 & 0.05 & 267 & 284 \\
\hline 17 & 7.0 & 60 & 0.8 & 0.05 & 169 & 156 \\
\hline 18 & 12 & 60 & 0.8 & 0.05 & 107 & 143 \\
\hline 19 & 7.0 & 60 & 1.2 & 0.05 & 265 & 203 \\
\hline 20 & 12 & 60 & 1.2 & 0.05 & 280 & 268 \\
\hline 21 & 9.5 & 55 & 1.0 & 0.04 & 294 & 282 \\
\hline 22 & 9.5 & 65 & 1.0 & 0.04 & 184 & 172 \\
\hline 23 & 9.5 & 55 & 1.0 & 0.06 & 265 & 252 \\
\hline 24 & 9.5 & 65 & 1.0 & 0.06 & 216 & 203 \\
\hline 25 & 9.5 & 60 & 1.0 & 0.05 & 305 & 305 \\
\hline 26 & 9.5 & 60 & 1.0 & 0.05 & 305 & 305 \\
\hline 27 & 9.5 & 60 & 1.0 & 0.05 & 305 & 305 \\
\hline 28 & 9.5 & 60 & 1.0 & 0.05 & 305 & 305 \\
\hline 29 & 9.5 & 60 & 1.0 & 0.05 & 305 & 305 \\
\hline
\end{tabular}

Table 2. Analysis of variance (ANOVA) for the quadratic polynomial model of glucoamylase production.

\begin{tabular}{|c|c|c|c|c|}
\hline Source & Sum of Squares & Mean Square & F value & \\
\hline Model & $1.235 \mathrm{E}+0014$ & 8823.99 & 13.75 & $<0.0001$ Significant \\
\hline A-Substrate & 1976.331 & 1976.33 & 3.08 & 0.1011 \\
\hline B-Moisture & 19120.081 & 19120.08 & 29.60 & $<0.0001$ \\
\hline C-Sucrose & 22188.001 & 22188.00 & 34.58 & $<0.0001$ \\
\hline D-Tryptone & 0.751 & 0.75 & 1.169E-003 & 0.9732 \\
\hline$\overline{\mathrm{AB}}$ & 0.251 & 0.25 & $3.896 \mathrm{E}-004$ & 0.9845 \\
\hline$\overline{\mathrm{AC}}$ & 1482.251 & 1482.25 & 2.31 & 0.1508 \\
\hline$\overline{\mathrm{AD}}$ & 4225.001 & 4225.00 & 6.58 & 0.0224 \\
\hline $\mathrm{BC}$ & 17822.251 & 17822.25 & 27.77 & 0.0001 \\
\hline $\mathrm{BD}$ & 930.251 & 930.25 & 1.45 & 0.2485 \\
\hline $\mathrm{CD}$ & 625.001 & 625.00 & 0.97 & 0.3404 \\
\hline$\overline{\mathrm{A}^{2}}$ & 8602.211 & 8602.21 & 13.41 & 0.0026 \\
\hline$\overline{\mathrm{B}^{2}}$ & 1371.631 & 1371.63 & 2.14 & 0.1658 \\
\hline $\mathrm{C}^{2}$ & 37138.021 & 37138.02 & 57.88 & $<0.0001$ \\
\hline$\overline{\mathrm{D}^{2}}$ & 25778.931 & 25778.93 & 40.17 & $<0.0001$ \\
\hline Residual & 8983.4214 & 641.67 & & \\
\hline Lack of Fit & 8983.4210 & 898.34 & & \\
\hline Pure Error & 0.0004 & 0.000 & & \\
\hline Cor Total & $1.325 \mathrm{E}+0028$ & & & \\
\hline
\end{tabular}


The experimental data for glucoamylase production by multiple regression equation as explained by the second order polynomial equation shown below:

$$
\begin{aligned}
\mathrm{Y}= & 305.00+12.83 \mathrm{~A}-39.92 \mathrm{~B}+43.00 \mathrm{C}+0.25 \mathrm{D}+0.25 \mathrm{AB} \\
& +19.25 \mathrm{AC} 32.50 \mathrm{AD}+66.75 \mathrm{BC}+15.25 \mathrm{BD} \\
& +12.50 \mathrm{CD}-36.42 \mathrm{~A}^{2}-14.54 \mathrm{~B}^{2}-75.67 \mathrm{C}^{2}-63.04 \mathrm{D}^{2}
\end{aligned}
$$

The Box-Behnken design shows predicted value on the basis of the above polynomial equation. Statistical analysis of variance (ANOVA) was done

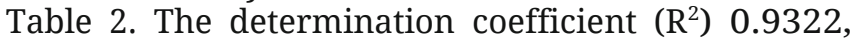
which means $93.22 \%$ variability in the response could be explained by this model. The model is stronger and predicts better response while $\mathrm{R}^{2}$ value is earlier to 1.0 (14). The value of the adjusted determination coefficient (adjusted $\mathrm{R}^{2}$ ) is 0.8644 . This upper value of adjusted $\mathrm{R}^{2}$ suggested the better significance of the model (15). A smaller value of the coefficient of variation (C.V. 11.18\%) indicates improved precision and dependability of the experiments executed. The F- value of 13.75 implies that the model is significant.

The 3D response surface plots recognise the interaction effects of medium components and optimum concentration of all components necessary for maximum glucoamylase production. Fig. 1 shows response surface curves for dissimilarity in glucoamylase production were constructed (1). In this study, two variables varied within their experimental series, whereas the other variables remained constant at zero levels. Six validation experiments (Table 1) statistically represented that the experimentally strong yield value of $313 \mathrm{U} / \mathrm{gds}$ was in close agreement to predicted $306 \mathrm{U} / \mathrm{gds}$. The results validate to the previous model with substrate amount (12 gm), moisture (55\%), sucrose (1.0 gm), tryptone (0.05) had the most excellent combination of factors used for obtaining highest glucoamylase production and thus confirming the model's accuracy.

\section{Purification of glucoamylase}

The precipitate obtained by chilled acetone was lyophilised and used for further purification by ionexchange chromatography using a DEAE-Cellulose column. The column was equilibrated with $0.1 \mathrm{M}$ acetate buffer ( $\mathrm{pH}$ 4.8). The lyophilised sample was eluted with a $\mathrm{NaCl}$ gradient $(0-1 \mathrm{M})$. The elution profile is shown in Fig. 2. The fraction corresponding to the major peak was used for further study. The enzyme activity of this fraction was determined.

The single band of the purified enzyme a showed molecular mass of about $66.0 \mathrm{Kda}$, which indicates

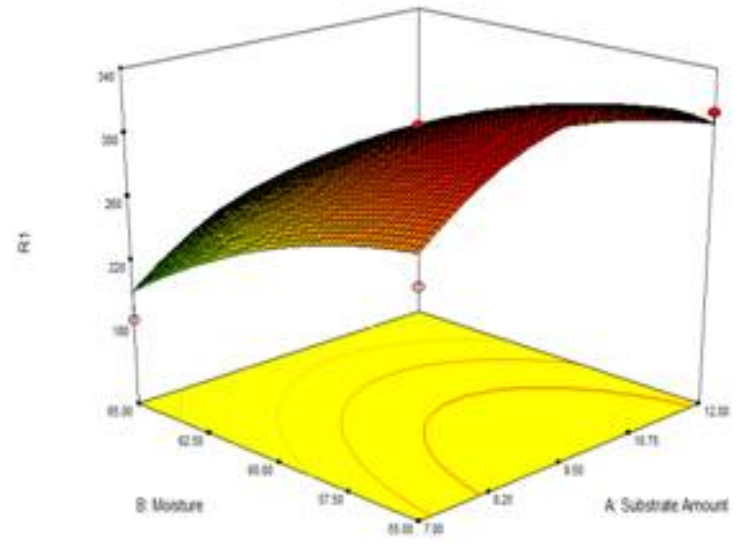

(A)

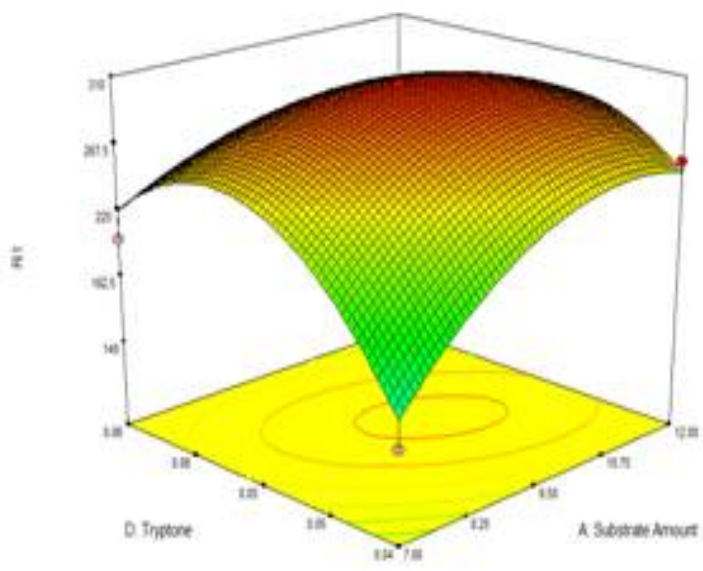

(C)

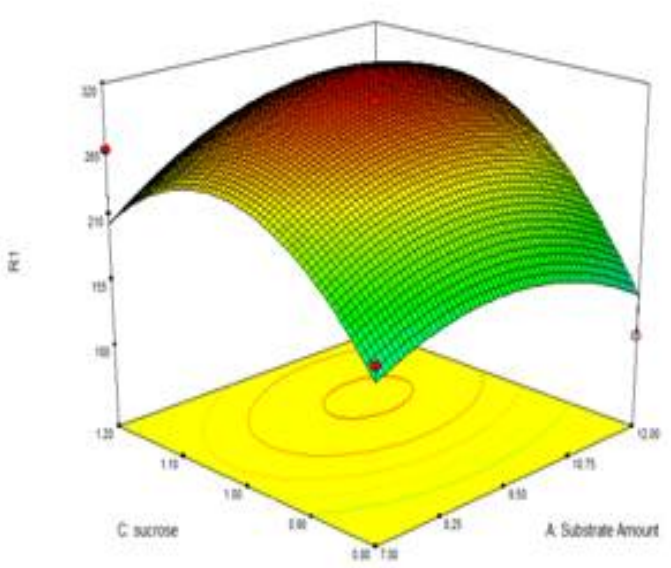

(B)

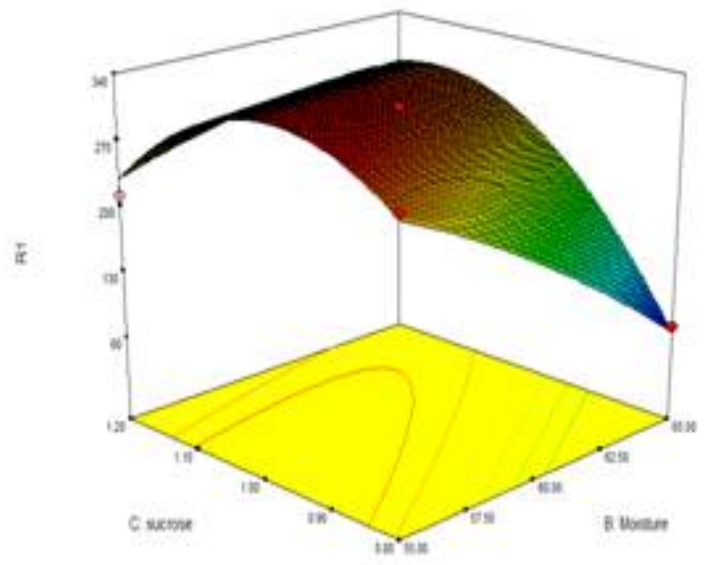

(D)

Fig. 1. Response surfacecurves of glucoamylase production from Aspergillus niger showing interaction between (A) substrate amount and moisture, (B) substrate amount and sucrose, (C) substrate amount and tryptone, (D) moisture and sucrose. 


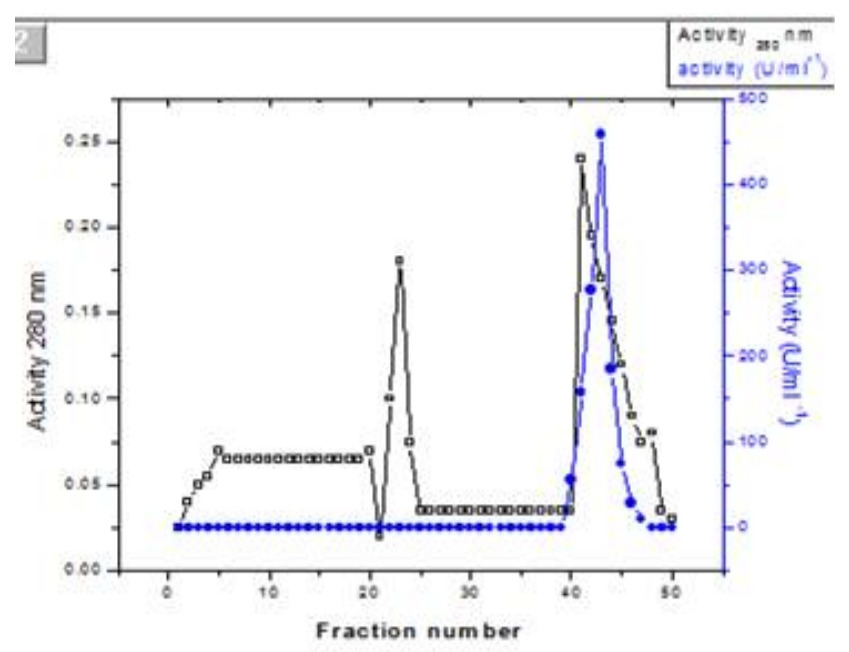

Fig. 2. Elution profile of glucoamylase from Aspergillus niger in DEAE-cellulose column chromatography.

the enzyme consisting of a single polypeptide chain. SDS-PAGE was done to determine the molecular mass of the protein fraction (Fig. 3).

\section{Characterization of the glucoamylase}

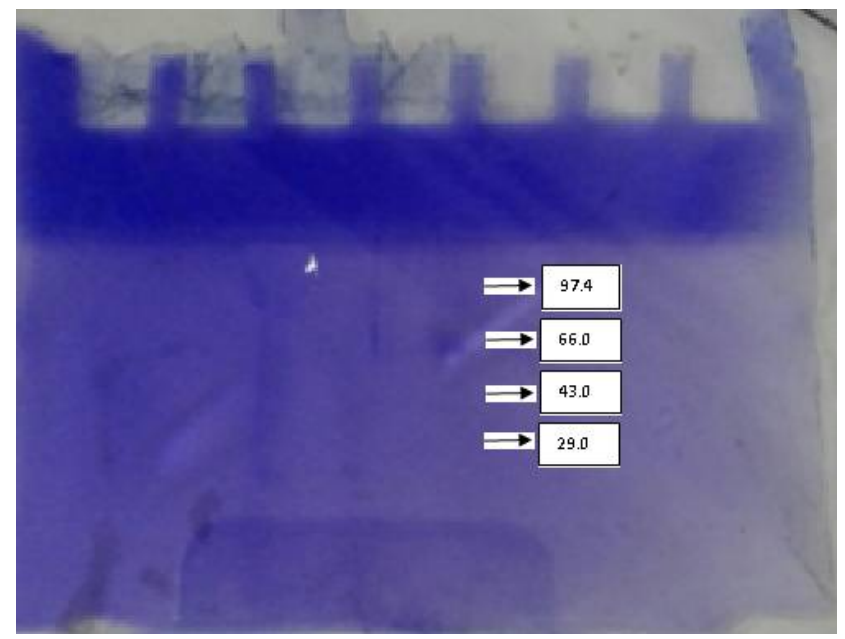

Fig. 3. SDS-PAGE of the purified glucoamylase.

Note: The molecular weight of standard protein used was Phosphorylase b (97.4 kDa.), Bovin Serum Albumin (66.0 kDa), Ovalbumin (43.0 kda), Carbonic Anhydrase (29.0 kDa). Line 1crude enzyme; Line 2 partially purified; Line 3 purified enzyme extract.

Effect of temperature and thermal stability of glucoamylase

The enzyme showed activity in the temperature range of $30-80{ }^{\circ} \mathrm{C}$. The maximum activity obtained was $370 \mathrm{U} / g d s$ at $60{ }^{\circ} \mathrm{C}$ (Fig. 4). Further, enhance temperature enzyme activity was decreased. This can be due to an increase in the rate of denaturation of the enzyme with a rise in temperature. This study agreed with (16) while they show the maximum activity of glucoamylase purified from Penicillium camemberti PL21 was at $30^{\circ} \mathrm{C}$.

In case of thermal stability about $400 \mathrm{U} / g d s$ was retained at $60{ }^{\circ} \mathrm{C}$. The retention of enzyme activity was more than $357 \mathrm{U} / g d s$ even at $70^{\circ} \mathrm{C}$. These suggest that glucoamylase is active over a wide range of temperature (Fig. 5).

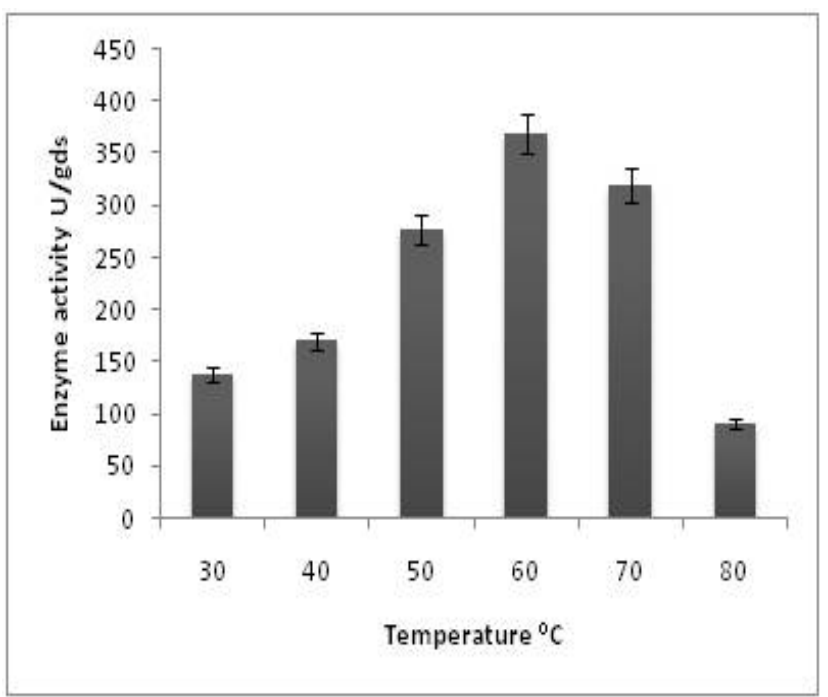

Fig. 4. Effect of temperature on glucoamylase activity.

Effect of pH and pH stability of glucoamylase

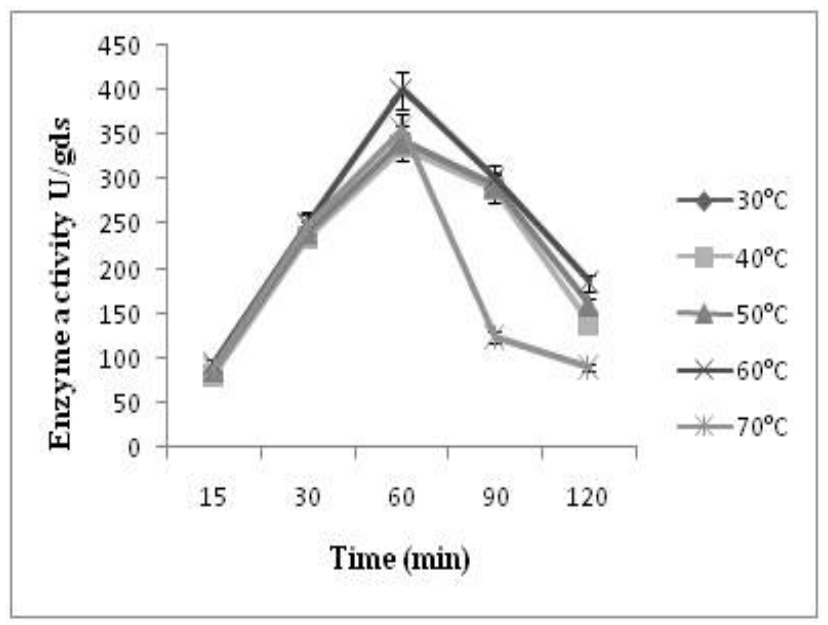

Fig. 5. Effect of temperature on the stability of glucoamylase.

The enzyme was active in the $\mathrm{pH}$ range of 4-8 with an optimal activity of $983 \mathrm{U} / \mathrm{gds}$ at pH5. After $\mathrm{pH} \mathrm{5}$, a continuous decrease in enzyme activity was observed (Fig. 6). Some researches pointed to the optimum $\mathrm{pH}$ of glucoamylase stability (17) and depicted that the

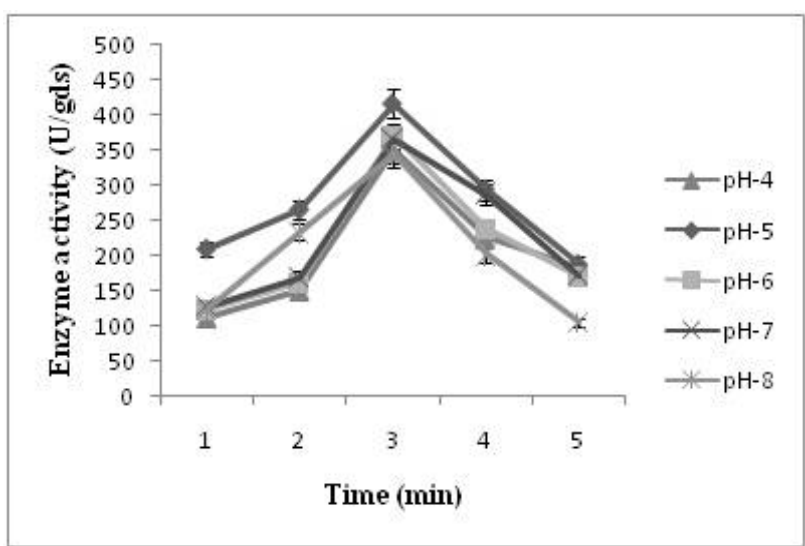

Fig. 6. Effect of $\mathrm{pH}$ on glucoamylase activity. 
optimum $\mathrm{pH}$ of glucoamylase stability purified from Marine Endophytic Aspergillus sp. JAN-25 ranges between 4-6.5.

For the enzyme extract, the stability of $\mathrm{pH}$ range was 4.0-8.0 respectively in a different time: $15 \mathrm{~min}, 30$ min, $60 \mathrm{~min}, 90 \mathrm{~min}$ and $120 \mathrm{~min}$. In case of $\mathrm{pH}$ stability about $416 \mathrm{U} / \mathrm{gds}$ was retained at $\mathrm{pH}$ 5. Even at pH 7 more than $366 \mathrm{U} / \mathrm{gds}$ of $\mathrm{pH}$ stability was maintained by the enzyme, showing that glucoamylase is active over a wide range of $\mathrm{pH}$. (Fig. 7).

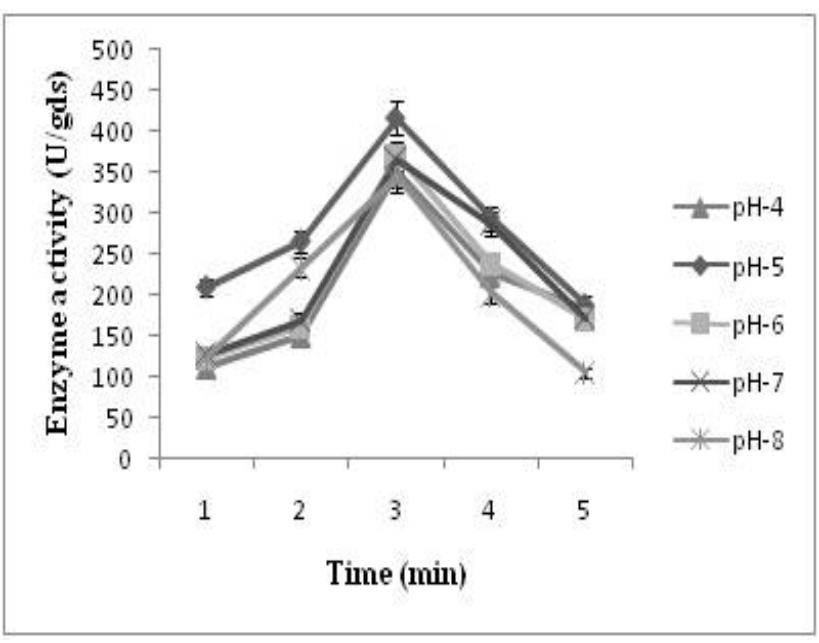

Fig. 7. Effect of $\mathrm{pH}$ on stability of glucoamylase.

To study the impact of various substrates, concentrations ranging from 1-5 \% were used. Reaction rate versus substrate concentration curve was plotted to determine whether the enzyme obeys Michaelis-Menten kinetics (Fig. 8). $K_{m}$ value is $6.17 \times 10^{-5} \mathrm{mg} / \mathrm{ml}$ and $\mathrm{V}_{\max } 526.3 \mathrm{U} / \mathrm{gds}$.

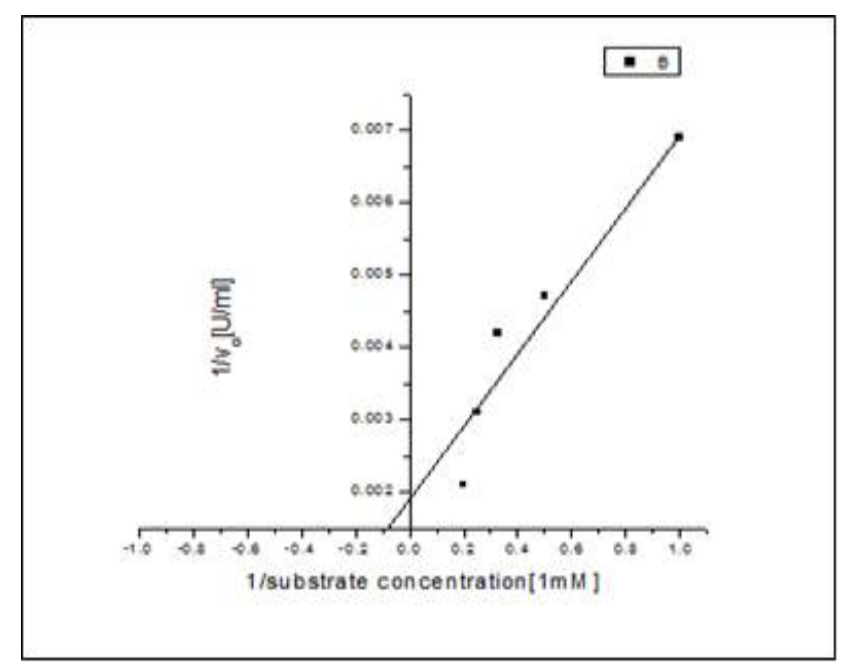

Fig. 8. Kinetic parameters of glucoamylase.

\section{Conclusion}

The obstacles to the commercial application of glucoamylase are the lack of enough enzyme stocks and the price of production of the enzyme. Enhancement of the enzyme production by modifying physiological conditions during the growth of fungi is a prerequisite for their optimum utilisation at an industrial scale. It can be concluded that increased production of glucoamylase under SSF as described in the present study is likely to be advantageous from ecological as well as biotechnological prospects. The characterisation of glucoamylase revealed some exclusive feature like stability over broad $\mathrm{pH}$ and temperature that render it as a possible applicant for commercial purpose. The finding of the present study is likely to be useful in further upgradation of the process.

\section{Acknowledgements}

The authors gratefully acknowledge the financial assistance from the University Grants Commission, New Delhi (Grant number: F1-17.1/2017-18/RGNF2017-18-SC-WES-44887/(SA-III/Website).

\section{Authors' contributions}

This work was carried out in collaboration with all authors. TP and UG designed the study. TP performed the statistical analysis, wrote the protocol and the first draft of the manuscript. UG and TP managed the analyses of the study. TP managed the literature searches. All authors read and approved the final manuscript.

\section{Conflict of interests}

The authors declare that they have no conflict of interests.

\section{References}

1. Prakasham RS, Rao CS, Rao RS, Sarma PN. Enhancement of acid amylase production by an isolated Aspergillus awamori. J Appl Microbiol. 2007;102:204-11. https://doi.org/10.1111/ j.1365-2672.2006.03058.x

2. Burhan A, Nisa U, Gokhan C, Omer C, Ashbil A, Osman G. Enzymatic properties of novel thermostable, thermophilic, alkaline and chelator resistant amylase from an alkaliphilic Bacillus sp. Isolate ANT-6. Process. Biochem. 2003;38:1397-403. https://doi.org/10.1016/S0032-9592(03)00037-2

3. Park Y, Kang S, Lee SW, Hong JS, Kim SW. Xylanase production in solid state fermentation by Aspergillus niger mutant using statistical experimental design. Appl Microbiol Biotechnol. 2002;58:761-66. https://doi.org/10.1007/s00253002-0965-0

4. Kumar S, Satyanarayana T. Statistical optimisation of a thermostable and neutral glucoamylase production by a thermophilic mold Thermomucor indicae-seudaticae in solid state fermentation. World J Microbiol Biotechnol. 2004;20:895902. https://doi.org/10.1007/s11274-004-2891-z

5. Gonzales GV, Torres EF, Aguilar CN, Gomez SJR, Godinez GD, Augur C. Advantage of fungal enzyme production in solid state over liquid fermentation system. Biochem Eng J. 2002;3643:1-11

6. Gupta A, Khare SK. Enhanced production and characterisation of a solvent stable protease from solvent tolerant Pseudomonas aeruginosa Psea Enz Microbial Technol. 2007;42:11-16. https:// doi.org/10.1016/j.enzmictec.2007.07.019

7. Anbu P, Annadural G, Hur KB. Production of alkaline protease from a newly isolated Exiguobacterium profundam BK- P23 evaluated using the response surface methodology. Biologia. 2013;68(2):186-93. https://doi.org/10.2478/s11756-013-0159-5 
8. Rao JLUM, Satyanarayana T. Statistical optimisation of a high maltose-forming, hyperthermostable and $\mathrm{Ca} 2+$ independent a-amylase production by an extreme thermophile Geobacillus thermoleovorans using response surface methodology. J App Microbiol. 2003;95:712-18. https://doi.org/10.1046/j.13652672.2003.02036.x

9. Malik S, Iftikhar T, Haq IU. Enhanced amyloglucosidase biosynthesis through mutagenesis using Aspergillus niger. Pak J Bot. 2011;43(1):111-19.

10. Polley T, Ghosh U. Statistical optimisation of alkaline protease production using isolated strain by submerged fermentation. JABB. 2016;7(4):1-8. https://doi.org/10.9734/JABB/2016/2740

11. Negi S, Banerjee R. Optimisation of extraction and purification of glucoamylase produced by Aspergillus awamori in solid state fermentation. Biotechnol Bioproc E. 2009;14:60-66. https://doi.org/10.1007/s12257-008-0107-3

12. Suhartati YT, Hadi S. Purification and characterisation of extracellular a amylase enzyme from local bacteria isolate Bacillus subtilis. Eur J Sci Res. 2010;39(1):64-74.

13. Deshmukh KB, Taur SA, Cherekar MN, Kothari MN, Pathak AP. Process optimisation, purification and characterisation of glucoamylase from different Sorghum varieties. 2011;3(2):73237.

14. Polley T, Ghosh U. Isolation and identification of potent alkaline protease producing microorganism and optimisation of biosynthesis of the enzyme using RSM. Indian Chem Eng. 2018;60(3):285-96.

https://doi.org/10.1080/00194506.2017.1376600

15. Cao Y, Meng DJ, Lu J, Long J. Statistical optimisation of xylanase production by Aspergillus niger AN-13 under submerge fermentation using response surface methodology. Afr J Biotechnol. 2008;7(5):631-38.

16. Nouadri T, Zahia M, Djekrif DS, Bennamoun L. Purification and characterisation of the glucoamylase isolated from Penicillium camemberti PL21. Afr J Biochem Res. 2012;4(6):155-62.

17. Mervat MA. Production of glucoamylase by marine endophytic Aspergillus sp. JAN-25 under optimised solid-state fermentation conditions on agro residues. Aust J Basic Appl Sci. 2012; 6(4):41-54. 